\title{
THE PROBLEMS INHERENT IN \\ LITIGATING EMPLOYER \\ FREE EXERCISE RIGHTS
}

\author{
HENRY L. CHAMBERS JR. *
}

INTRODUCTION

I. THE SUPREME COURT'S RECENT EMPLOYER FREE

EXERCISE CASES

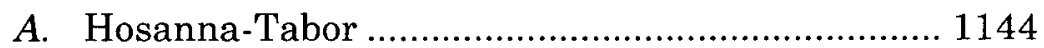

B. Hobby Lobby ...................................................... 1147

II. PRoviding FREE EXERCISE RIGHTS TO EMPLOYERS ... 1149

A. Employers Are Not Necessarily the Alter Egos of Their Owners

B. Corporate Acts Are Not Limited to the Acts of Owners

1. Respondeat Superior 1154

2. Sexual Harassment 1155

C. Gathering Shared Religious Belief in the

Corporate Employer

1. The Individual Nature of Religious Belief ...... 1157

2. The Purpose of the Entity ................................ 1159

III. EXPANSION OF EMPLOYER PREROGATIVE .................... 1161

A. Employer Freedom Flowing from Recent Cases ... 1162

B. Overclaiming Free Exercise Rights ....................... 1164

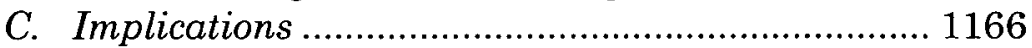

IV. DANGERS OF IGNORING EMPLOYEE INTERESTS ........... 1167

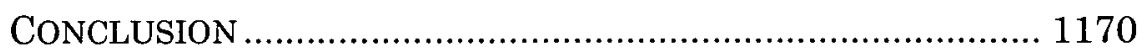

\section{INTRODUCTION}

Cases in which employers argue for the existence or expansion of their religious free exercise rights tend to be litigated as if the employer and the government are the true

* Professor of Law, University of Richmond School of Law. The author thanks all who made the symposium possible. 
adversaries. ${ }^{1}$ Structuring such litigation as employer versus government seems sensible because the First Amendment regulates the relationship between the government and its people, in part, by limiting the government's power to legislate regarding religion. ${ }^{2}$ Typically, the adjudication of First Amendment rights defines and alters the relationship between the government and the litigant. For example, when a statute that limits a litigant's free exercise rights directly or indirectly is invalidated, governmental power is pruned and the litigant's freedom expands. ${ }^{3}$ As long as the employer is a constitutional "person," the government-versus-employer structure appears accurate. However, that characterization is incomplete.

When an employer's free exercise rights are at issue, the employer's employees are also real adversaries. The expansion of an employer's free exercise rights broadens the employer's ability to structure the workplace as it wants and narrows the employees' statutory rights. ${ }^{4}$ The employer's gain is the employees' loss. The narrowing of employee rights is a byproduct of the employment at-will rule-the default rule in nearly every state-which allows an employer to fire an employee for almost any reason. ${ }^{5}$ Employment statutes and other public policy principles functionally limit the employment

1. See, e.g., Hosanna-Tabor Evangelical Lutheran Church \& Sch. v. EEOC, 132 S. Ct. 694, 701-02 (2012) (noting that the key issue in the employment discrimination case is whether the First Amendment allows the government to interfere in a church's selection of its minister through application of the Americans with Disabilities Act (ADA)).

2. See U.S. Const. amend. I ("Congress shall make no law respecting an establishment of religion, or prohibiting the free exercise thereof.").

3. See, e.g., Hosanna-Tabor, 132 S. Ct. at 710 (holding that the ministerial exception barred ADA claim from being brought); see also Burwell v. Hobby Lobby Stores, Inc., 134 S. Ct. 2751, 2785 (2014) (invalidating part of Affordable Care Act (ACA) in the face of a challenge based on the Religious Freedom Restoration Act's (RFRA's) right to exercise religion).

4. An employer is not an employer unless it has employees who will be affected by the employer's actions. See, e.g., 42 U.S.C. $\S 2000$ e(b) ("The term 'employer' means a person engaged in an industry affecting commerce who has fifteen or more employees ...."); 42 U.S.C. $\$ 2000 \mathrm{e}$ (f) ("The term 'employee' means an individual employed by an employer....").

5. See Samuel Estreicher \& Jeffrey M. Hirsch, Comparative Wrongful Dismissal Law: Reassessing American Exceptionalism, 92 N.C. L. REV. 343, 443 (2014) (noting that Montana is the only state that appears to deviate from an atwill rule). For general discussions of the at-will employment rule, see Rachel Arnow-Richman, Mainstreaming Employment Contract Law: The Common Law Case for Reasonable Notice of Termination, 66 FLA. L. REV. 1513 (2014); Richard Bales, Explaining the Spread of At-Will Employment as an Interjurisdictional Race to the Bottom of Employment Standards, 75 TENN. L. REV. 453 (2008). 
at-will rule by eliminating some of the reasons an employer may terminate an employee. When the expansion of employer free exercise rights limits the reach of an employment statute or regulation, the employer's latitude to structure the workplace as it wants broadens. The employer's ability to fire those who do not like how the employer structures the workplace widens as the rights that the employer's employees may exercise under the now limited statute narrow. ${ }^{6}$ When the constitutional free exercise rights of employers are expanded, the statutory rights of employees tend to be restricted, with employees suffering decreased protection against workplace harm by the employer. ${ }^{7}$ Consequently, courts that adjudicate employer free exercise rights ought to consider the rights of employees as central to the dispute.

In its recent employer free-exercise cases, Hosanna-Tabor Evangelical Lutheran Church \& School v. EEOC (HosannaTabor) ${ }^{8}$ and Burwell v. Hobby Lobby Stores, Inc. (Hobby Lobby), ${ }^{9}$ the Supreme Court affirmed religious freedom rights for employers as though it were affirming the religious free exercise rights of individuals against government intrusion. ${ }^{10}$ The decisions largely declined to analyze the effects they would have on the employees involved. The Court's treatment of the adjudication of an employer's free exercise rights as an adversarial dispute between the employer and the government that merely concerns the limitation of government power over the employer is problematic. Given the effect such litigation can have on employee rights, the Court should reframe how it decides such litigation and directly consider the rights of employees in deciding similar cases.

This brief Article proceeds in four parts. Part I discusses the Supreme Court's recent cases that address employer free exercise rights. Part II notes problems that accompany providing free exercise rights to employers. Part III explores

6. For example, the application of the ministerial exception, a functional expansion of an employer's free exercise rights, negates any rights ministers may have had under employment discrimination statutes to be free of disability discrimination. See Hosanna-Tabor, 132 S. Ct. at 710.

7. See, e.g., Cannata v. Catholic Diocese of Austin, 700 F.3d 169, 170 (5th Cir. 2012) (barring Age Discrimination in Employment Act (ADEA) and ADA claims in the face of employer's ministerial exception).

8. Hosanna-Tabor, 132 S. Ct. 694.

9. Burwell v. Hobby Lobby Stores, Inc., 134 S. Ct. 2751 (2014).

10. The Court alternately claimed that it was protecting the right of the individual owners of the companies. See Hobby Lobby, 134 S. Ct. at 2468. 
the expansion of employer prerogative in the context of providing employers additional free exercise rights. Part IV considers problems that arise when employee rights are not deemed central to litigation regarding employer free exercise rights. The Article concludes by proposing a reframing of the free exercise issue that will consider how to account for the interests of the employer, its stakeholders, and its employees in employer free exercise cases.

\section{The SUPREME COURT's RECENT EMPLOYER FrEE EXERCISE CASES}

In its last few terms, the Supreme Court has decided two particularly important employer free exercise cases. HosannaTabor involved a religious employer. ${ }^{11}$ Hobby Lobby involved employers whose owners were devoutly religious. ${ }^{12}$ In each case, the Court extended the employer's free exercise rights and narrowed employees' statutory-based rights. ${ }^{13}$ The Court did not seriously consider employee rights as a counterbalance to the extension of the employer's free exercise rights in either case.

\section{A. Hosanna-Tabor}

In Hosanna-Tabor, the Court held that the ministerial exception bars an employment discrimination suit filed by a minister challenging her termination by her religious employer. ${ }^{14}$ That exception-derived from the Free Exercise and Establishment clauses of the First Amendment-allows a religious employer to fire a minister for any reason without regard to employment discrimination statutes that would otherwise limit such termination. ${ }^{15}$ In Hosanna Tabor, the defendant church school fired Cheryl Perich, one of its

11. See Hosanna-Tabor, 132 S. Ct. at 699.

12. See Hobby Lobby, 134 S. Ct. at 2764-66.

13. See Hosanna-Tabor, $132 \mathrm{~S}$. Ct. at 710 . There is a dispute between the Hobby Lobby majority and dissent regarding whether any employees lost the right to any contraceptives under the ACA. Hobby Lobby, 134 S. Ct. at 2759-60, 2787 (Ginsburg, J., dissenting). However, the exemption that appears to be required under Hobby Lobby may affect how employees may receive the contraceptives at issue. See id.

14. Hosanna-Tabor, 132 S. Ct. at 710.

15. Id. at 701 . 
teachers, when she pushed to regain her job at the school after a medical leave. ${ }^{16}$ The school argued that because Perich was a minister, the ministerial exception allowed the school to fire her without having to defend its reason for the firing. ${ }^{17}$ Though the dispute was between an employer and an employee about an employment matter, the employer's First Amendment religious rights controlled the decision. ${ }^{18}$

Perich was initially hired as a lay teacher at the school. ${ }^{19}$ After religious instruction, she was "called" by the congregation and was commissioned as a minister. ${ }^{20}$ She then became a called teacher at the school. ${ }^{21}$ After Perich was diagnosed with narcolepsy, she began the next school year on medical leave. ${ }^{22}$ Eventually, a lay teacher was hired to cover her job for the remainder of the school year. ${ }^{23}$ During that school year, Perich was cleared to return to work by her physician, but was told by the school that she could not return to work that year. ${ }^{24}$ The church congregation offered to release Perich from her call in return for payment of a portion of her health insurance premiums if she would resign from her job. ${ }^{25}$ Perich declined to resign and appeared for work. ${ }^{26}$ She was told there was no longer a job for her at the school. ${ }^{27}$ In response, she threatened to sue.28 In the ensuing weeks, the congregation rescinded Perich's call, and she was fired as a teacher the day after her call was rescinded. ${ }^{29}$

Perich sued, arguing that the church school had violated the Americans with Disabilities Act. ${ }^{30}$ The school argued that

16. The Court deemed the church to have fired Perich. See id. at 700, 710. However, given that the chairman of the school's board was involved in the firing and she was a teacher at the school, the school arguably fired her. Id.

17. Id. at 702 ("Both Religion Clauses bar the government from interfering with the decision of a religious group to fire one of its ministers.").

18. Id. at 710 .

19. Id. at 700 .

20. Id. at $699-700$ (discussing the process of being called and noting that Perich "receive[d] the formal title "Minister of Religion, Commissioned" after taking the call).

21. Id. at 700 (noting that Perich became a called teacher during her tenure).

22. Id. at 700 .

23. Id.

24. Id.

25. Id.

26. Id.

27. Id.

28. Id.

29. Id.

30. Id. at 701. 
the ministerial exception protected its decision and released it from any obligation to justify Perich's firing. ${ }^{31}$ In response, Perich argued that even though she was a minister, her teaching job was not a position to which the ministerial exception should apply. ${ }^{32}$ The Court agreed with the school, noting that the ministerial exception stems from the principle that the government cannot regulate the affairs of religious entities. ${ }^{33}$ A statute that forces a religious employer to retain a minister the employer does not want to retain deprives the employer of its freedom to freely control "those who will personify its beliefs," and must yield. ${ }^{34}$ Consequently, the church school was free to fire the minister, regardless of the effect such firing had on the employee. ${ }^{35}$ As a result, a dispute that began as an employment discrimination suit ended as a free exercise suit pitting the rights of a religious employer against the government's right to regulate the employment relationship. The absolute nature of the ministerial exception makes many rights that the employee may appear to have subject to the employer's free exercise rights, against the government. ${ }^{36}$ Perich's rights to be free of discrimination on the basis of disability and free of retaliation for pressing her employment rights were lost and were barely discussed by the Court. ${ }^{37}$

31. Id.

32. Not surprisingly, given that Perich was originally hired as a lay teacher and had been replaced by a lay teacher, the Court struggled to determine whether the position was a ministerial position. See id. at 707-09; see also Kirby v. Lexington Theological Seminary, 426 S.W.3d 597, 606 (Ky. 2014) (noting that the Hosanna-Tabor Court "appeared to take an approach akin to a review of the totality of the circumstances" in determining who is a minister).

33. Hosanna-Tabor, 132 S. Ct. at 705-06; see also Kirby, 426 S.W.3d at 605 (asserting that the ministerial exception makes a court incompetent to hear employment discrimination claims by ministers against their religious employers).

34. Hosanna-Tabor, $132 \mathrm{~S}$. Ct. at 706.

35. See id.

36. Id. at 710 ("The case before us is an employment discrimination suit brought on behalf of a minister, challenging her church's decision to fire her. Today we hold only that the ministerial exception bars such a suit.").

37. However, she may retain other rights against the school. Id. at 710 ("We express no view on whether the exception bars other types of suits, including actions by employees alleging breach of contract or tortious conduct by their religious employers."); see also Kirby, 426 S.W.3d at 602 (holding that contract claims for firing may be viable though the ministerial exception bars employment discrimination claims against employer). 


\section{B. Hobby Lobby}

In Hobby Lobby, the Supreme Court ruled that a closelyheld, for-profit corporation must be exempted, based on the exercise of its free exercise religious rights, from a regulation requiring that an employer provide certain benefits to its employees under the Patient Protection and Affordable Care Act (ACA). ${ }^{38}$ The ACA requires that covered employers provide preventive care and screenings for women without cost sharing with the employee. ${ }^{39}$ Pursuant to the ACA, the Department of Health and Human Services (HHS) developed regulations to specify what health care benefits covered employers must provide. ${ }^{40} \mathrm{HHS}$ determined that covered employers were to provide certain forms of contraception to its employees. ${ }^{41}$ HHS exempted some religious, non-profit employers from its regulations, but did not exempt for-profit corporations otherwise required to provide coverage under the ACA. ${ }^{42}$ The plaintiffs-all closely-held, for-profit companies-argued that providing or being tangentially involved in providing some of the required forms of contraception would violate their strongly held religious beliefs. ${ }^{43}$ Each plaintiff-employer had been founded by individuals or families with strong religious beliefs and had been run in conformity with those beliefs. ${ }^{44}$

Though Hobby Lobby was decided under the Religious Freedom Restoration Act (RFRA), rather than directly under the First Amendment, the employer's free exercise rights were at issue because RFRA protects a person's (including a corporation's) exercise of religion. ${ }^{45}$ The Court acknowledged the free exercise rights of the corporate employers, though it noted that recognition of such corporate rights is meant to

38. See Burwell v. Hobby Lobby Stores, Inc., 134 S. Ct. 2751, 2759 (2014).

39. See id.

40. See id. at 2759 .

41. See id. at $2762-63$.

42. See id. at $2762-64$.

43. See id. at $2765-66$.

44. See id. at $2764-66$.

45. See id. at 2767 ("RFRA prohibits the 'Government [from] substantially burden[ing] $a$ person's exercise of religion even if the burden results from a rule of general applicability' unless the Government 'demonstrates that application of the burden to the person-(1) is in furtherance of a compelling governmental interest; and (2) is the least restrictive means of furthering that compelling governmental interest."' (quoting 42 U.S.C. $\S \S 2000 \mathrm{bb}-1$ (a), (b))). 
protect the rights of the owners of the corporation. ${ }^{46}$ The first key issue under RFRA is whether a person's exercise of religion is substantially burdened by the government's action. ${ }^{47}$ The Court found that HHS's regulations substantially burdened the plaintiffs' exercise of religion. ${ }^{48}$ The second key issue under RFRA is whether the government's action is justified by a compelling governmental interest and represents the least restrictive means of furthering the government's interest. ${ }^{49}$ The Court found that HHS's regulations were not the least restrictive means of promoting the government's interests and invalidated them. ${ }^{50}$

Hobby Lobby was decided as if it directly pitted the religious rights of the employer against the right of the government to regulate the employer-employee relationship through the ACA. The government's right to regulate the employer through the ACA and the employer's complementary right to be free of government intrusion became the central issues in the litigation, with the rights that employees might lose through the invalidation of HHS regulations being largely ignored. ${ }^{51}$ To be clear, the Hobby Lobby majority claimed that the employees' right to contraception was untouched by the ruling. ${ }^{52}$ Indeed, the Court did not believe it needed to analyze the employees' right to contraception because, it believed, such

46. Id. at 2768 (noting that protecting a corporation is a legal fiction with the purpose "to provide protection for human beings").

47. Id. at 2775 .

48. See id. at $2775-79$.

49. See id. at 2779 .

50. See id. at 2781-82. Some religious entities have argued that an exemption from the ACA's requirements is not enough. See, e.g., Priests for Life v. U.S. Dep't of Health \& Human Servs., 772 F.3d 229 (D.C. Cir. 2014) (arguing that the exemption may yet make them party to providing contraception and like medical treatment); Little Sisters of the Poor Home for the Aged v. Sebelius, 6 F. Supp.3d 1225 (D. Colo. 2013), appeal docketed, No. 13-1540 (10th Cir., Dec. 27, 2013).

51. Hobby Lobby, $134 \mathrm{~S}$. Ct. at 2759 ("We must decide in these cases whether the Religious Freedom Restoration Act of 1993 (RFRA), 107 Stat. 1488, 42 U.S.C. $\S 2000$ bb et seq., permits the United States Department of Health and Human Services (HHS) to demand that three closely held corporations provide healthinsurance coverage for methods of contraception that violate the sincerely held religious beliefs of the companies' owners. We hold that the regulations that impose this obligation violate RFRA, which prohibits the Federal Government from taking any action that substantially burdens the exercise of religion unless that action constitutes the least restrictive means of serving a compelling government interest.").

52. See id. at $2759-60$. 
rights were unaffected by the ruling. ${ }^{53}$ Conversely, the dissent argued that the Court's analysis improperly ignored the decision's potential effects on employees. ${ }^{54}$ In addition, the dissent suggested that if similar issues arose with respect to a refusal to provide different medical care to which the employer objected on religious grounds, such as blood transfusions, the majority's approach would tend to allow the employer's religious beliefs to trump the rights of employees, without serious discussion of either the employer's objections or of the employee's interests. ${ }^{55}$ The majority responded that, if issues arose with respect to other forms of medical care, its analysis would consider all possible implications of providing a religious exemption. ${ }^{56}$ Nonetheless, the Court's position left unresolved precisely how the Court may consider employee rights in the future when employer free exercise rights are at issue.

How employee rights ought to be factored into employer free exercise cases is an important issue that must be addressed. However, a preliminary issue regarding the structure of employer free exercise cases must be examined first. The decisions in Hosanna-Tabor and Hobby Lobby depend on granting employers free exercise rights as if they were natural persons. Part II explores whether treating employers in this way is sensible.

\section{Providing Free Exercise Rights to EmPloyers}

The Supreme Court has determined that certain employers can exercise religion-based statutory and constitutional rights. ${ }^{57}$ The basis for the Court's decisions appears to be that an employer's free exercise rights represent the aggregation of

53. See id. at 2780 .

54. Id. at 2787 (Ginsburg, J., dissenting) ("In the Court's view, RFRA demands accommodation of a for-profit corporation's religious beliefs no matter the impact that accommodation may have on third parties who do not share the corporation owners' religious faith-in these cases, thousands of women employed by Hobby Lobby and Conestoga or dependents of persons those corporations employ.").

55. See id. at 2805 (Ginsburg, J., dissenting).

56. See id. at 2783 .

57. When non-religious rights are provided to corporations to protect the corporate assets, providing such rights may seem sensible. See id. at 2768 ("Protecting corporations from government seizure of their property without just compensation protects all those who have a stake in the corporations' financial well-being."). 
the free exercise rights of particular stakeholders who are closely associated with the employer. ${ }^{58}$ Conceiving of employer rights in such a manner and allowing the exercise of such rights by an employer based on that conception is problematic. First, an employer is not necessarily the alter ego of its owners/ stakeholders and is responsible for more than the acts of its owners/stakeholders. Second, the idiosyncratic nature of religious belief suggests that free exercise rights typically ought to be extended only to natural persons. Third, even if the collective free exercise rights of its stakeholders can be reasonably located in a corporate employer, such collectivization usually would be sensible only when the employer was created solely to facilitate the exercise of those free exercise rights, i.e., as a church or its equivalent.

\section{A. Employers Are Not Necessarily the Alter Egos of Their Owners}

A corporate employer is not usually considered an alter ego of its owners capable of exercising the same rights as those owners. ${ }^{59}$ This is true even when the corporate employer is owned by a single person. ${ }^{60} \mathrm{~A}$ key purpose of incorporation is to create an entity that is separate from its owners, with separate rights and responsibilities. ${ }^{61}$ Indeed, the Supreme Court has held that a corporation is not merely a reflection of its owners. ${ }^{62}$ Rather than allow an owner to exercise constitutional rights through its corporation, the Court has, in some circumstances, limited an owner from exercising personal constitutional rights precisely because the owner's corporation

58. See id. at 2768 (" $[\mathrm{P}]$ rotecting the free-exercise rights of corporations like Hobby Lobby, Conestoga, and Mardel protects the religious liberty of the humans who own and control those companies.").

59. Cf. United States v. Peters, 732 F.3d 93, 102-03 (2d Cir. 2013) (discussing, though ultimately not using, the doctrine of piercing the corporate veil that is used when a party wants to treat a corporate owner as the alter ego of the corporation).

60. The term "corporate employer" is used loosely to include corporations and collective entities that consist of more than a single natural person, e.g., partnerships, associations, LLCs and the like.

61. Indeed, it is rare that the separation will not be honored. When the separation is not honored, courts are deemed to have pierced the corporate veil. See United States v. Bestfoods, 524 U.S. 51 (1998).

62. See, e.g., Cedric Kushner Promotions, Ltd. v. King, 533 U.S 158, 166 (2001) (noting "that the corporation and its employees are not legally identical"). 
was involved. 63

In Braswell $v$. United States, the Court ruled that an owner of a corporation could not assert Fifth Amendment rights that he would have been able to assert had he run his business as a sole proprietorship. ${ }^{64}$ At issue was how to treat certain business documents that had been subpoenaed. ${ }^{65}$ Although business documents generally are not privileged, the act of producing the documents pursuant to a subpoena can be deemed to have testimonial significance that can trigger Fifth Amendment protection for the person who produces the documents. ${ }^{66}$ The act of producing the documents is the equivalent of testifying that the documents are authentic and are responsive to the subpoena. ${ }^{67}$ Consequently, a person whose act of production may be incriminating may have the right to receive immunity under the Fifth Amendment for that act of production before being forced to produce the documents. ${ }^{6}$

The business documents of a sole proprietorship are treated as personal documents of the owner rather than as corporate business documents. The owner of a sole proprietorship is generally entitled to immunity for the act of producing such documents if the owner's act of producing the documents is incriminating. ${ }^{69}$ Conversely, corporate business documents are treated as the corporation's documents. ${ }^{70}$ Their production comes with no Fifth Amendment protection for the person who produces the documents. ${ }^{71}$ Consequently, the Braswell Court was faced with determining how to treat the documents of a corporation that was run essentially as a sole

63. The Court's jurisprudence is not necessarily consistent. Compare Braswell v. United States, 487 U.S. 99, 104 (1988) ("[W]e have long recognized that, for purposes of the Fifth Amendment, corporations and other collective entities are treated differently from individuals. This doctrine-known as the collective entity rule-has a lengthy and distinguished pedigree."), with Burwell v. Hobby Lobby Stores, Inc., 134 S. Ct. 2751, 2768 (2014) ("[E]xtending Fourth Amendment protection to corporations protects the privacy interests of employees and others associated with the company.").

64. See Braswell, 487 U.S. at 104.

65. Id. at 101.

66. Id. at 101-02.

67. Id. at 118.

68. See, e.g., United States v. Hubbell, 530 U.S. 27 (2000).

69. See Braswell, 487 U.S. at 104.

70. See id. at 105.

71. See id. at 114-15. 
proprietorship. ${ }^{72}$ After running his business as a sole proprietorship for approximately fifteen years, Braswell incorporated the business and became sole owner and shareholder of the company. ${ }^{73}$ Though his wife and mother served as corporate officers, Braswell had full and sole authority over the corporation's business affairs. ${ }^{74}$ Consequently, he argued that the corporate documents at issue should be treated as if they were the documents of a sole proprietorship. ${ }^{75}$ Had the Court agreed with Braswell's argument, Braswell's act of production would have had the same testimonial significance as if he were still running the business as a sole proprietor, and he would have been granted immunity for his act of production. ${ }^{76}$ However, the Court disagreed. ${ }^{77}$

The Court explained that collective entities, such as corporations and partnerships, have no Fifth Amendment rights. ${ }^{78}$ Subpoenas for corporate documents are requests made of the corporation, even though the subpoena might be directed to the custodian of corporate records. ${ }^{79}$ The custodian provides those records as the corporation's agent, rather than in a personal capacity. ${ }^{80}$ The custodian's act of production is the corporation's act of production, so it cannot be a basis for act-ofproduction immunity for the custodian even though the act of production may incriminate the custodian. ${ }^{81}$ This is so even though the documents would have been treated as the owner's documents had the corporation been run as an unincorporated sole proprietorship, with Braswell entitled to act-of-production immunity. ${ }^{82}$ Thus, Braswell's loss of Fifth Amendment rights

72. See id. at 101-02.

73. Id. at $100-01$.

74. Id. at 101.

75. Braswell argued that the size and nature of the corporation was such that it should have been treated as his alter ego. See id. at 102.

76. See id. at 101-02.

77. See id. at 118-19.

78. Id. at 102.

79. The subpoena at issue was directed to Braswell personally. See id. at 101. The government noted that it addresses subpoenas to individuals so that it may force the individual to comply with the subpoena. See id. at 118.

80. See id. at 118 (noting that the act of production is the corporation's act).

81. Id. at 112 .

82. Id. at 104 ("Had petitioner conducted his business as a sole proprietorship, Doe would require that he be provided the opportunity to show that his act of production would entail testimonial self-incrimination."). 
was a cost of incorporation. ${ }^{83}$

A corporation is separate from its sole owner and shareholder in other contexts as well. For example, in Cedric Kushner Promotions $v$. King, the Court treated the president/ sole shareholder and his corporation as separate entities for purposes of the Racketeer Influenced and Corrupt Organizations Act (RICO) ${ }^{84} \mathrm{RICO}$, in part, prohibits a person from conducting or participating in the conduct of an enterprise's affairs through a pattern of racketeering activity, i.e., multiple crimes. ${ }^{85}$ The Supreme Court has interpreted the Act to require that the enterprise and the person committing the crime be separate entities. ${ }^{86}$ The Court determined that the corporation and its sole owner were distinct entities, noting, "The corporate owner/employee, a natural person, is distinct from the corporation itself, a legally different entity with different rights and responsibilities due to its different legal status." 87 Indeed, a corporation usually is legally separate from its owner, even when the owner acts on the corporation's behalf. 88

83. Not surprisingly, that troubled the dissent. See id. at 130 (Kennedy, J., dissenting) ("Braswell was the sole stockholder of the corporation and ran it himself. Perhaps that is why the Court suggests he waived his Fifth Amendment self-incrimination rights by using the corporate form. One does not always, however, have the choice of his or her employer, much less the choice of the business enterprise though which the employer conducts its business."). There is an irony that the Court was so hostile to Braswell's claims but very solicitous of Hobby Lobby's claims. See Burwell v. Hobby Lobby Stores, Inc., 134 S. Ct. 2751, 2759 (2014) ("In holding that the HHS mandate is unlawful, we reject HHS's argument that the owners of the companies forfeited all RFRA protection when they decided to organize their businesses as corporations rather than sole proprietorships or general partnerships.").

84. Cedric Kushner Promotions, Ltd. v. King, 533 U.S. 158, 161-62 (2001).

85. 18 U.S.C. § 1962(c) (2012); Kushner, 533 U.S. at 160.

86. Kushner, 533 U.S. at 160-61.

87. Id. at 163. The Court continued, "After all, incorporation's basic purpose is to create a distinct legal entity, with legal rights, obligations, powers, and privileges different from those of the natural individuals who created it, who own it, or whom it employs." Id.

88. The Kushner Court's focus on the owner also being an employee of the company is of no moment, as corporations may only act through their agents and employees. Anything done on the entity's behalf must be done by someone else or some other entity. Indeed, there is an irony in that the Court has suggested in other circumstances that an owner with administrative duties is generally not considered an employee of the entity. For a discussion of who may qualify as an employee, see Clackamas Gastroenterology Assocs., P. C. v. Wells, 538 U.S. 440 (2003). 


\section{B. Corporate Acts Are Not Limited to the Acts of Owners}

Even when owners' interests are precisely the same as their corporation's interests, a corporation consists of far more than its owners and their interests. The corporation is responsible for corporate acts, which may include the acts of its owners, officers, employees, and other agents acting on the corporation's behalf. ${ }^{89}$ The corporation cannot necessarily limit its responsibility for those acts, though it may attempt to control what acts are taken in its name. ${ }^{90}$ The corporation is more than just a manifestation of its owners' beliefs and is responsible for more than its owners' actions. ${ }^{91}$ Courts have made that clear through respondeat superior liability for corporations and sexual harassment liability for employers.

\section{Respondeat Superior}

A corporation may be responsible civilly or criminally for actions taken on its behalf, ${ }^{92}$ with corporate responsibility often taking the form of respondeat superior liability. ${ }^{93}$ Respondeat superior deems a corporation responsible for acts taken by agents or employees ostensibly for the benefit of the company, on the company's behalf, and in the scope of the employee's employment or the agent's agency. ${ }^{94}$ Such responsibility is reasonable because corporations act through their employees and agents. ${ }^{95}$ Indeed, corporations may be responsible for actions taken on its behalf even when an agent's actions are

89. See Faragher v. City of Boca Raton, 524 U.S. 775, 790 (1998) (noting that at times the act of a supervisor becomes a corporate act).

90. See, e.g., United States v. Potter, 463 F.3d 9, 26 (1st Cir. 2006) (noting that corporation may be liable for acts of agent or employee even when the agent or employee has been forbidden from taking those acts); United States v. Ionia Mgmt. S.A., 526 F. Supp. 2d 319, 324 (D. Conn. 2007) (noting that corporation may be held liable for agent's actions even when those actions are contrary to the corporation's instructions).

91. See Kushner, 533 U.S. at 166.

92. This has been so for over a century. See New York Cent. \& Hudson River R.R. v. United States, 212 U.S. 481 (1909). For a more recent example, see United States v. Singh, 518 F.3d 236 (4th Cir. 2008).

93. Corporate criminal liability under the Model Penal Code is more restrictive than under respondeat superior. See MODEL PENAL CODE $§ 2.07(1)$ (c).

94. See Singh, 518 F.3d at 249-50; Potter, 463 F.3d at 25.

95. See Kushner, 533 U.S. at 166; Braswell v. United States, 487 U.S. 99, 110 (1988) ("Artificial entities such as corporations may act only through their agents ...."). 
inconsistent with corporate policies. ${ }^{96}$ A corporation's policies may be its guiding principles, but a company may be deemed responsible for actions taken on its behalf, even if those actions are inconsistent with the company's policies or principles. ${ }^{97}$

\section{Sexual Harassment}

Employers may be liable for the acts of their agents and employees when those agents and employees violate employment discrimination laws. ${ }^{98}$ For example, employers may be responsible when agents or employees sexually harass other employees, even when the harassment does not serve the employer's interests. ${ }^{99}$ An employer may be responsible for the harassment even when the harassment is undertaken by employees for their own purposes and does not inure to the employer's benefit.100 Indeed, employers may be deemed responsible for acts occurring in the workplace, even when those acts are antithetical to the desires of the owners or highlevel management. 101

The Supreme Court has created a structure for assigning employer responsibility when sexual harassment occurs. ${ }^{102}$ When sexually harassing behavior yields actual tangible detriment to the employee's terms, conditions, or privileges (TCP) of employment or compensation, the employer will be

96. See United States v. Hilton Hotels Corp., 467 F.2d 1000 (9th Cir. 1972) (noting that a corporation can be held responsible for actions taken contrary to its corporate policies); see also Burlington Indus. v. Ellerth, 524 U.S. 742, 756 (1998).

97. See, e.g., United States v. Basic Constr. Co., 711 F.2d 570, 573 (4th Cir. 1983) (noting that corporation can be held criminally liable for actions taken contrary to corporate policy).

98. Title VII makes employers liable for the acts of their agents. See 42 U.S.C. $\S 2000 \mathrm{e}(\mathrm{b})$ (2012) (including "agent of employer" within the definition of employer).

99. See Faragher v. City of Boca Raton, 524 U.S. 775, 793-94 (1998) (noting that sexual harassment may not normally be in employee's scope of employment).

100. Some sexual harassment may be in the employer's interest. A workplace that functions more smoothly overall with an atmosphere that could be considered harassing may condone harassment. However, that is usually not the case. See id. at 794 (" $[\mathrm{T}]$ he courts have emphasized that harassment consisting of unwelcome remarks and touching is motivated solely by individual desires and serves no purpose of the employer.").

101. See Ellerth, 524 U.S. at 757 ("The harassing supervisor often acts for personal motives, motives unrelated and even antithetical to the objectives of the employer.").

102. See id. at 752-53; Faragher, 524 U.S. at 790; Vance v. Ball State Univ., 133 S. Ct. 2434, 2441 (2013). 
liable under Title VII for such harassment. ${ }^{103}$ The employer is liable, in part, because actual job detriment cannot occur unless someone cloaked with authority from the employer acts. ${ }^{104}$ For example, an employee is not terminated until the employer, in the form of an agent with authority, fires the employee. ${ }^{105}$ When coworkers harass an employee and constructively alter the employee's TCP of employment, they trigger hostile work environment (HWE) harassment, for which the employer will be liable if the employer negligently allowed the harassment. ${ }^{106}$ Employer responsibility is trickiest when a supervisor's conduct triggers HWE harassment. Under those circumstances, the Court deems the employer vicariously liable for supervisor-caused HWE harassment, subject to an affirmative defense. ${ }^{107}$ The two-part affirmative defense requires that the employer have a reasonable system for deterring or remedying harassment and that the employee unreasonably fail to use the system. ${ }^{108}$ This careful allocation of responsibility is based on the supposition that an employer may be responsible for some, but should not necessarily be responsible for all, workplace activity that it reasonably attempted to prevent. 109

The Court's sexual harassment doctrine confirms that an employer can be deemed responsible for actions taken by employees and agents on the employer's behalf. Employers cannot avoid liability merely by suggesting that their

103. See Faragher, 524 U.S. at 786 . Such harassment is usually called quid pro quo harassment. See Ellerth, 524 U.S. at 752-53.

104. See id. at 761-62 (noting that a supervisor's act is effective because it is an act that the employer has empowered the supervisor to take).

105. See id. ("A tangible employment action constitutes a significant change in employment status, such as hiring, firing, failing to promote, reassignment with significantly different responsibilities, or a decision causing a significant change in benefits. . Tangible employment actions are the means by which the supervisor brings the official power of the enterprise to bear on subordinates.").

106. Vance, $133 \mathrm{~S}$. Ct. at 2439 (noting negligence standard applies to determine employer liability for co-worker harassment that yields HWE).

107. See Faragher, 524 U.S. at 807.

108. See id. at 805 (noting the two-part affirmative defense requires "that the employer had exercised reasonable care to avoid harassment and to eliminate it when it might occur, and that the complaining employee had failed to act with like reasonable care to take advantage of the employer's safeguards and otherwise to present harm that could have been avoided"); Vance, $133 \mathrm{~S}$. Ct. at 2439 (noting the two-part affirmative defense against supervisor-triggered HWE harassment).

109. See Faragher, 524 U.S. at 806 (discussing statutory policy that recognizes that employers who seek to prevent sexual harassment should be able to avoid liability in some circumstances). 
employee's acts were not consistent with the employer's sexual harassment policies. The Court has been careful in attempting to determine which employee acts should be considered the acts of the employer. However, the Court never questioned that some acts of employees should be considered acts of the employer for which the employer is responsible, even when those actions do not reflect the employer's policies or values.

\section{Gathering Shared Religious Belief in the Corporate Employer}

The Supreme Court has recognized the free exercise rights of some corporate employers in two contexts: where the employer's owners are deeply religious and where the employer is a religious organization. ${ }^{110}$ The Court does so by gathering or collectivizing the free exercise rights of some of the employer's stakeholders and treating those rights as though they are the free exercise rights of the employer. 11 That is particularly problematic when the employer is a for-profit corporation. It is somewhat less troubling when the employer is a religious organization.

\section{The Individual Nature of Religious Belief}

The individual and idiosyncratic nature of religious belief makes treating the religious beliefs of an employer's owners as the religious beliefs of the employer difficult to justify. Those who share very similar religious beliefs may find that those beliefs lead individuals to varied conclusions even when those beliefs are applied to a common set of facts. Disputes abound at the highest levels of churches regarding how to apply doctrine, even among clergy who presumably share the same religious beliefs. 12 That any group of people, but especially lay people,

110. Title VII specifically allows certain religious employers to discriminate in employment on the basis of religion. See 42 U.S.C. $\S 2000$ e-1(a) (2012); 42 U.S.C. § $2000 \mathrm{e}-2(\mathrm{e})$ (2012) (detailing religious employer exemptions for religious discrimination). Title VII does not provide such employers exemptions to discriminate on any of Title VII's other bases.

111. See Burwell v. Hobby Lobby Stores, Inc., 134 S. Ct. 2751, 2768 (2014) (noting that protecting the free exercise rights of the corporation merely protects the free exercise rights of the corporation's owners).

112. See, e.g., Henry L. Chambers, Jr. \& Isaac A. McBeth, Much Ado About Nothing Much: Protestant Episcopal Church in the Diocese of Virginia v. Truro Church, 45 U. RICH. L. REV. 141, 142-46 (2010) (discussing the Episcopal 
can share religious beliefs so completely that those religious principles can be sensibly treated as one for purposes of running a corporation they jointly own may not be realistic.

Religious beliefs can be deeply personal. A religious belief need not be central to a person's religion or even recognized by the person's religion at all to be treated as a religious belief that must be legally protected. ${ }^{113}$ Indeed, the belief need not be associated with any particular religion, or with religion at all, 114 and can be unreasonable, yet still be protected. ${ }^{115}$ The belief must be honored almost without question, no matter how idiosyncratic, if it is sufficiently deeply held by the individual. ${ }^{116}$

Given all of these complications, it is unclear whether the religious beliefs of multiple owners can be identified and transmitted to a corporate body as a single belief structure in any coherent fashion. ${ }^{17}$ Certainly, a group of owners may agree that a corporate policy sufficiently reflects their religious beliefs to be acceptable to all owners. ${ }^{118}$ However, that is not the same as suggesting that the owners' beliefs constitute a single, shared corporate belief structure on which corporate free exercise rights can or should rest. That is, rarely can an

Church's internal disputes regarding homosexual clergy); Laurie Goodstein \& Elisabetta Povoledo, No Consensus at Vatican as Synod Ends, N.Y. Times (Oct. 18, 2014), available at http://www.nytimes.com/2014/10/19/world/europe/noconsensus-at-vatican-as-synod-ends-.html, archived at http://perma.cc/UV2S33NM (discussing a contentious Catholic synod of bishops that discussed how the Church should address issues of homosexuality and divorce).

113. See Davis v. Ft. Bend Cnty., 765 F.3d 480, 485 (5th Cir. 2014) (noting that courts cannot inquire into whether a religious belief is "central to the religion" or "a true religious tenet"); Chenzira v. Cincinnati Children's Hosp. Med. Ctr., No. 1:11-CV-00917, 2012 WL 6721098, at *4 (S.D. Ohio Dec. 27, 2012) (noting possibility that veganism can be protected as a moral or ethical belief akin to a religious belief).

114. See Davis, 765 F.3d at 485 (noting that covered religious beliefs need only be "moral or ethical beliefs as to what is right and wrong which are sincerely held with the strength of traditional religious views" (quoting 29 C.F.R. $\S 1605.1$ (2015))).

115. See Burwell v. Hobby Lobby Stores, Inc., 134 S. Ct. 2751, 2778 (2014) (noting that courts have no authority to determine whether religious beliefs are reasonable).

116. Davis, 765 F.3d at 486 (noting that the key to protection is not whether the belief is a religious tenet, but whether the belief is religious and the party "sincerely believed [the belief] to be religious in her own scheme of things").

117. Identification of shared belief is necessary not to prove sincerity, but to make sure that the corporation's desire to avoid the strictures of the law is religion-based and not business-based.

118. See Hobby Lobby, 134 S. Ct. at 2771. 
employer be considered to be exercising its own free exercise rights, rather than merely asserting the disparate free exercise rights of its owners. Alternatively, it is just as possible that corporate policy merely reflects the religious beliefs of the employer's most powerful owner. However, if the employer's sole purpose is to facilitate the free exercise rights of its stakeholders, allowing the employer to exercise the collective free exercise rights of its stakeholders may be sensible.

\section{The Purpose of the Entity}

The Supreme Court has suggested that a corporate employer's free exercise rights merely constitute the collection of free exercise rights of certain stakeholders in the employer. ${ }^{119}$ That may be sensible when the employer is a church or church-related entity, but may make little sense otherwise. The Court suggests that free exercise rights provided to some corporate employers can be provided to similar corporate employers on similar terms. ${ }^{120}$ Consequently, providing free exercise rights to Hosanna-Tabor (a church school) is similar to providing free exercise rights to Hobby Lobby (a for-profit corporation owned by devout people).121 The Court is correct that the form of the entity is arguably irrelevant. A church that is a corporation ought to have the same free exercise rights as an unincorporated church. However, it is not apparent why a for-profit corporation should enjoy the same free exercise rights as a church that is a corporation. ${ }^{122}$ The collectivization of the free exercise rights of church members in a church is more easily justified than the collectivization of the free exercise rights of owners of a forprofit business. ${ }^{123}$

119. See id. at 2768 (noting that Congress provided protection for owners by including "corporations" in RFRA's definition of "persons").

120. See id. at 2770.

121. See id. at 2769-73 (explaining that for-profit and non-profit corporations alike are covered by RFRA and its protection of the exercise of religion).

122. The Hobby Lobby majority might disagree. See id. at 2769-70 (suggesting that both for-profit and non-profit corporations can exercise religion).

123. See Corp. of the Presiding Bishop of the Church of Jesus Christ of LatterDay Saints v. Amos, 483 U.S. 327, 342 (1987) (Brennan, J., concurring) ("For many individuals, religious activity derives meaning in large measure from participation in a larger religious community. Such a community represents an ongoing tradition of shared beliefs, an organic entity not reducible to a mere aggregation of individuals."). 
Collectivizing the free exercise rights of church members in a church is understandable because a church's members adhere to the church's doctrine. ${ }^{124}$ Though the individual members of the church may apply the doctrine differently, it is the church's doctrine that they are trying to apply. The church is a manifestation of its membership's free exercise of religion. To the extent that free exercise is about following whatever religion one believes, collectivizing the free exercise rights of followers of the same church or religion is reasonable. The adherents come to the church and presumably want to reflect the church. Any mismatch between an individual adherent's interpretation of church doctrine and actual church doctrine reflects the adherent's mistake, rather than the church's mistake. ${ }^{125}$ Nonetheless, it is the free exercise rights of church members that are protected by protecting the church's free exercise rights. Consequently, though the church arguably should technically have no free exercise rights of its own, allowing the church to exercise or facilitate its members' collective free exercise rights by deeming that exercise to be the church's free exercise of religion may be sensible. ${ }^{126}$

The collectivization of the free exercise rights of multiple owners in their corporation is far less coherent. Even if all the owners of an entity share a similar religious viewpoint and the owners attempt to use the entity to advance their free exercise rights, it is unclear that a for-profit corporate entity has a shared religious viewpoint. Except in very rare instances, a forprofit corporation is meant to reflect its owners. ${ }^{127}$ The owners do not adhere to the corporation; the corporation adheres to its owners. ${ }^{128}$ Consequently, siting the owners' free exercise rights in the corporation appears precisely backward. The corporation's actions can and should reflect the owners' devotion to religious principles. However, there is no claim that the corporation guides the owners, rather than vice versa.

124. See Henry L. Chambers, Jr., Slavery, Free Blacks and Citizenship, 43 RUTGERS L.J. 487, 493-94 (2013) (discussing adherence and church membership).

125. Of course, if a church member chooses a religious belief that is not a part of church doctrine, that belief is protected as well. See supra notes 114-16 and accompanying text.

126. The Court's language may appear to suggest otherwise. See, e.g., Hobby Lobby, $134 \mathrm{~S}$. Ct. at 2794-95 (focusing directly on the church's religious rights rather than the religious rights of parishioners).

127. See Hobby Lobby, 134 S. Ct. at 2768.

128. See id. ("Corporations, 'separate and apart from' the human beings who own, run and are employed by them, cannot do anything at all."). 
Where to site the free exercise rights of individuals is a difficult issue. Principally, such rights should be sited in the individual. Gathering them in a church and allowing the church to exercise the rights collectively makes some sense in that the church exists to facilitate the individuals' free exercise of religion. ${ }^{129}$ Gathering the free exercise rights of individuals in a for-profit business makes little sense because the corporation is a mere extension of its owners. The corporation may reflect the owners' values, but it does not necessarily exist to facilitate the owners' free exercise of religion. This suggests that the Court ought, in many cases, to focus directly on the free exercise rights of individual stakeholders rather than treating them as the rights of the employer, even when a church exercises them collectively. Before that issue is addressed, the manner in which providing free exercise rights directly to employers affects the workplace should be addressed. Part III discusses how the expansion of the free exercise rights of employers, church-related and not, broadens the employers' prerogative to structure the workplace as those employers see fit.

\section{EXPANSION OF EMPLOYER PREROGATIVE}

By broadening the free exercise rights of employers, the Supreme Court has widened the latitude employers have to make some employment decisions without considering limitations imposed by federal law, including employment discrimination law. ${ }^{130}$ That is the result of invalidating some applications of statutes that infringe on the constitutional rights of employers. ${ }^{131}$ However, the outer edge of the scope of the employer's latitude is not clear, as the Court's decisions have not provided clear restrictions on how much religious-

129. Indeed, the church can be deemed a repository of religious rights. See Hosanna-Tabor Evangelical Lutheran Church \& Sch. v. EEOC, 132 S. Ct. 694, 706 (2012) (noting that the First Amendment "gives special solicitude to the rights of religious organizations").

130. That latitude can already be pretty broad. Not only can a religious organization fire or refuse to hire an employee whose religious beliefs are inconsistent with the organization's, an employee may not be allowed to sue for harassment or retaliation based on religion. See Kennedy v. St. Joseph's Ministries, Inc., 657 F.3d 189 (4th Cir. 2011).

131. See Corp. of the Presiding Bishop of the Church of Jesus Christ of LatterDay Saints v. Amos, 483 U.S. 327, 334 (1987) (noting that government may be required to accommodate an entity's religious practices). 
minded employers can restructure the workplace and impose workplace rules consistent with their beliefs. The uncertainty regarding the employer's freedom to ignore statutes that protect employee rights guarantees that the scope of an employee's statutory employment rights will be fuzzy.

\section{A. Employer Freedom Flowing from Recent Cases}

Consistent with Hosanna-Tabor and Hobby Lobby, employers have new freedom to shape their workplaces. At the least, employers presumably can do what Hosanna-Tabor and Hobby Lobby were allowed to do in their cases. A church school should be allowed to fire a called teacher without justifying the action. ${ }^{132}$ A closely-held, for-profit company with devoutly religious owners, who hold the same religious objections as Hobby Lobby's owners, should be allowed to decline involvement in providing the types of contraception to which Hobby Lobby objected. ${ }^{133}$ The bigger question is what other actions employers may take based on the reasoning underlying the two cases.

Employers ought to be allowed to do whatever an objectively reasonable reading of Hobby Lobby and HosannaTabor allows them to do. However, employers may instead attempt to do whatever they subjectively believe Hobby Lobby and Hosanna-Tabor should allow them to do. A reasonable interpretation of Hobby Lobby would appear to suggest that the owners of a closely held, for-profit corporation can run the corporation consistent with the owners' religious beliefs and avoid the strictures of some parts of the ACA relating to contraception if those strictures substantially affect the owners' free exercise rights. ${ }^{134}$ Employers could interpret Hobby Lobby to cover additional types of corporations and to allow religioninspired restrictions on additional forms of health care, employee benefits and health-related activity. ${ }^{135}$ Similar issues

132. See Hosanna-Tabor, 132 S. Ct. at 710; Herzog v. St. Peter Lutheran Church, 884 F. Supp. 2d 668 (N.D. Ill. 2012) (concerning the firing of a called teacher at a Lutheran school).

133. See Hobby Lobby, 134 S. Ct. at 2759.

134. See id.

135. See, e.g., Priests for Life v. U.S. Dep't of Health \& Human Servs., 772 F.3d 229, 246-47 (D.C. Cir. 2014) (describing the argument of religious groups that do not want to be involved in any way with providing contraception to employees); Herx v. Diocese of Fort Wayne-South Bend, No. 1:12-CV-122 RLM, 2014 WL 
exist with Hosanna-Tabor. Hosanna-Tabor allows a church school to fire a minister, but does not specify how to determine whether an employee is a minister or whether the court or the employer should make the decision. ${ }^{136}$ An employee need only serve in a ministerial capacity to be subject to the ministerial exception; the employee need not be an ordained minister. Congregations may be, or may believe themselves to be, relatively free to define which of their employees are ministers or serve in a ministerial capacity. ${ }^{137}$ Given that ministers can be fired for any reason, the ability to define who is a minister is the ability to define to whom the employment discrimination laws will apply. 138 That can have serious implications, particularly for workers who may not have considered themselves ministers. ${ }^{139}$

The Court has provided no clear stopping point for how far employers can push their religious beliefs into the workplace. The Court may be unable to put fundamental limitations on the expansion of the free exercise rights of certain employers given that constitutional rights are difficult to cabin and religious beliefs are difficult to define. Hosanna-Tabor and Hobby Lobby could be read broadly as holding that an employer's religious beliefs should trump government regulation whenever an individual's religious beliefs would trump government regulation. ${ }^{140}$ Such a reading might encourage an employer to exercise its religious rights until told to stop. If the cases are interpreted to suggest that protecting

4373617 , at ${ }^{*} 1$ (N.D. Ind. Sept. 3, 2014) (noting attempt to decline to renew teacher's contract because she had undergone in vitro fertilization, which Diocese viewed as "gravely immoral").

136. See Kirby v. Lexington Theological Seminary, 426 S.W.3d 597, 606-07 (Ky. 2014) (discussing the uncertainty of the Hosanna-Tabor Court's analysis).

137. Indeed, Justice Thomas would leave the decision solely to the good faith decision making of the church school. See Hosanna-Tabor, 132 S. Ct. at 710 (Thomas, J., concurring); see also Kirby, 426 S.W.3d at 611 (noting that some courts decline to decide who is a minister).

138. See Cannata v. Catholic Diocese of Austin, 700 F.3d 169, 180 (5th Cir. 2012) (deeming music director a minister). But see Herx v. Diocese of Fort WayneSouth Bend Inc., No. 1:12-CV-122 RLM, 2014 WL 4373617 (N.D. Ind. Sept. 3, 2014) (deeming language arts teacher not a minister).

139. See Kirby, 426 S.W.2d at 605 (noting that ministerial exception has been applied to more employees than those with the title "minister").

140. The Hobby Lobby Court would probably argue otherwise. Burwell v. Hobby Lobby Stores, Inc., 134 S. Ct. 2751, 2783 (2014) (suggesting that Hobby Lobby is a narrow decision and criticizing the claim that the decision could be read broadly to cover additional medical procedures). 
the free exercise rights of an employer is as much of a positive good as protecting the free exercise rights of individuals, the exercise of those rights-which are rights of conscience-ought to continue until the employer is required to stop. By not hinting at or indicating a reasonable stopping point for the expansion of an employer's constitutional free exercise rights, the Court also does not indicate a reasonable stopping point for the restriction of the rights of employees.

Providing no limitation on constitutional rights is sensible in regular constitutional adjudication involving the struggle between the individual and the government. Not specifying the limits of a constitutional right may be sensible when the expansion of a right primarily restricts the government. However, when the expansion of the employer's rights is so closely tied to the diminution of employee rights, the need for a relatively clear limitation arguably exists. If the Court cannot provide a reasonable limitation, it probably ought to reconsider whether employers, as entities, should be provided free exercise rights at all.

\section{B. Overclaiming Free Exercise Rights}

Hosanna-Tabor and Hobby Lobby extend the protection of employer free exercise rights in ways that may provide a cost incentive for the employer to exercise those rights. The ability to fire a minister without concern for violating an employment discrimination statute may be valuable. The ability to refuse to provide insurance for certain forms of health care may also be valuable. Even if the employer does not plan to save money through the exercise of such rights, if the rights can be asserted relatively costlessly, there may be an incentive to assert such rights, if only not to lose them. This is not cynical. Any activity that is costless may be more likely to be taken than if the activity were costly. ${ }^{141}$ Religious free exercise may be no different. ${ }^{142}$ That a free exercise right may be newly asserted

141. The effect of RFRA may be to make the choice less costly. See Hobby Lobby, $134 \mathrm{~S}$. Ct. at 2767 (suggesting that RFRA stops government from putting owners to the choice of "either giv[ing] up the right to seek judicial protection of their religious liberty or forgo[ing] the benefits, available to their competitors, of operating as corporations").

142. Consider the effects of making charitable religious contributions tax deductible. Even if parishioners are called to give, they may give more when a tax deduction is provided than when it is not provided. 
may not matter as long as the employer's or its owners' religious beliefs exist when the free exercise right is asserted. ${ }^{143}$

Expanding an employer's free exercise rights may trench on employee rights more broadly than is apparent. An employer acts through its employees and agents. ${ }^{144}$ Consequently, its religious rights will be protected and asserted by employees and agents, including management. Functionally, how those rights will be protected and asserted will depend on the religious prerogatives of whatever decision maker is cloaked with the employer's power. ${ }^{145}$ However, agents can misperceive the substance of an employer's religious views or agents can be too aggressive in asserting those religious views. ${ }^{146}$ An agent-employee responsible for implementing the employer's religious beliefs may substitute his or her own religious beliefs for the employer's beliefs, whether or not they align precisely with those beliefs. If the agent-employee misapprehends the employer's religious beliefs, the employer's beliefs will not be precisely reflected in the agent-employee's decision making or workplace rules. This is problematic, as religion-based decision making that abrogates the effect of statutes is allowed only because the employer's beliefs are religious and protected by the First Amendment. ${ }^{147}$ Unless an employee affected by the agent-employee's decision is willing to challenge the action and argue that the agentemployee's action was based on the improper application of the employer's religious beliefs, the decisions made based on the agent-employee's religious beliefs will stand. That appears to

143. New claims of religiosity should be just as reasonable as old claims of religiosity, if the claims are really derivative of the owners' claims of religiosity. See Trans World Airlines v. Hardison, 432 U.S. 63 (1977) (noting that the employee developed religious beliefs sometime after having been hired by employer but finding the beliefs protected anyway).

144. The Court has suggested that corporate employers may act only through their agents and employees. See Hobby Lobby, 134 U.S. at 2768; Braswell v. United States, 487 U.S. 99, 110 (1988).

145. Indeed, agency costs arguably rise when the owners are allowed to structure the workplace in a religious fashion and management refuses to do so.

146. In Kennedy v. St. Joseph's Ministries, Inc., the employer deemed an employee's attire inconsistent with the employer's religious doctrine after residents in the nursing home complained. 657 F.3d 189 (4th Cir. 2011). However, it was unclear whether the attire itself or the residents' reaction to the attire was the cause for the termination.

147. Consider a human resources director who defines who is a minister more broadly than the relevant congregation would. 
be a misapplication of the Court's judgment recognizing expanded employer free exercise rights. ${ }^{148}$

\section{Implications}

Free exercise cases are about freedom and prerogative. Personal prerogative or conscience in the form of free exercise rights may trump governmental regulation. ${ }^{149}$ However, when the entity seeking expanded free exercise rights is an employer, free exercise involves providing prerogative to the employer in the workplace. That can become a problem given that employment statutes often intentionally limit the prerogative that employers can exercise in the workplace. ${ }^{150}$

An employer's claim to additional free exercise rights tends to manifest itself as the freedom to fire an employee, the freedom to structure the workplace, or the freedom to make workplace decisions the employer wants to make, without government interference. ${ }^{151}$ However, employers already have substantial workplace prerogative. At-will employment, which allows an employer to fire an employee for almost any reason, is the default rule in almost all states. ${ }^{152}$ Employment discrimination statutes and public policy limit and regulate the at-will nature of employment. ${ }^{153}$ Those limitations are calibrated to make the employment relationship fairer than the relationship would be otherwise and to limit the prerogative of the employer. ${ }^{154}$ The expansion of an employer's free exercise rights may eventually leave the employee with the potentially unpalatable option of working at a workplace governed by

148. Both the Hosanna-Tabor and Hobby Lobby Courts have suggested that the opinions should be read relatively narrowly and as not restricting employee rights. See Hosanna-Tabor Evangelical Lutheran Church \& Sch. v. EEOC, 132 S. Ct. 694, 710 (2012); Hobby Lobby, 134 S. Ct. at 2783-84.

149. See Hosanna-Tabor, 132 S. Ct. 694 (2012) (trumping the ADA); Hobby Lobby, 134 S. Ct. 2751 (trumping Health and Human Services regulations promulgated pursuant to the ACA).

150. See 42 U.S.C. $§ 2000$ e-2(a) (2008) (limiting bases on which employer can alter the terms, conditions, or privileges of an employee's employment).

151. See Hosanna-Tabor, $132 \mathrm{~S}$. Ct. at 709 (noting that the ministerial exception gives the decision to hire or fire ministers to the church alone).

152. See supra note 5 and accompanying text.

153. See Estreicher \& Hirsch, supra note 5, at 347 ("In the United Statesabsent a constitutional, statutory, or public-policy provision or ruling restricting the grounds for termination-nothing prevents the employer or employee from terminating the employment relationship without cause or notice.").

154. See id. 
potentially limiting work rules allowed under the employer's newly recognized free exercise rights, or quitting.

The expansion or reinterpretation of an employer's free exercise rights can fundamentally alter the relationship between employee and employer. That change is particularly disruptive because employees have few options and employers already exercise significant prerogative in the workplace. Given that, employee rights should be at the core of the discussion of the employer's free exercise rights. Part IV briefly comments on the problems that attend not considering employee rights and interests when adjudicating an employer's free exercise rights.

\section{DANGERS OF IGNORING EMPLOYEE INTERESTS}

Given that providing free exercise rights to employers expands the employer's workplace prerogative and narrows employee rights, employee rights should be at the core of litigation regarding employer free exercise rights. They have not been. The Hosanna-Tabor Court ignored its ruling's effect on the employee; 155 the Hobby Lobby Court denied its ruling had any effect on the litigants' employees. ${ }^{156}$ Constitutional litigation involving employers is problematic because people whose interests need to be represented-the employees-may be ignored if the litigation is considered to focus primarily on the constitutional free exercise rights of the employer. This can be particularly troublesome because constitutional change can be near permanent. A decision grounded in statutory interpretation can be changed or its effects can be blunted. ${ }^{157}$ However, once a constitutional right exists, reversing course is very difficult. ${ }^{158}$

When the Court does not consider employee rights in adjudicating employer free exercise cases, it does not fully

155. See Hosanna-Tabor, 132 S. Ct. at 709 (noting that the point of the ministerial exception is to leave the decision to fire the minister to the church alone).

156. See Burwell v. Hobby Lobby Stores, Inc., 134 S. Ct. 2751, 2759-60 (2014).

157. For example, the Lilly Ledbetter Fair Pay Act of 2009, Pub. L. No. 111-2, 123 Stat. 5, created a statutory fix in response to Ledbetter v. Goodyear Tire \& Rubber Co., 550 U.S. 618 (2007).

158. See Neal Kumar Katyal, Legislative Constitutional Interpretation, 50 DUKE L.J. 1335, 1376-77 (2001) (discussing one-way ratchet argument that courts can expand individual constitutional rights but should not narrow constitutional rights). 
explore the possible implications of its decisions. Without the employee's point of view as a part of the discussion, courts tend to discount important employment discrimination goals, such as fairness and equal treatment. ${ }^{159}$ Similarly, the magnitude of the harm to the workplace is less clear when employees' interests are not considered. To be clear, this is not about subjecting the employer's free exercise rights to a general balancing test. Rather, it is about the Court determining how far prerogative should extend in the context of providing free exercise rights. 160 For example, even though a religious employer can fire a minister for any reason under HosannaTabor, the Court may eventually need to determine how much latitude an employer should have in determining whether an employee is a minister. That discussion might be better informed by a consideration of the statutory rights of the specific employee at issue as well as those of other employees in the workplace. In the absence of considering the effect a ruling may have on employee interests, the Court may allow too much latitude in the exercise of an employer's free exercise rights by failing to properly define (and thereby reasonably limit the scope of) an employer's free exercise rights.

Ignoring employee rights when adjudicating employer free exercise rights may seem sensible. Free exercise rights are constitutional rights that are supposed to trump mere statutes. ${ }^{161}$ Constitutional rights are also supposed to trump government prerogative as reflected in statutes. ${ }^{162}$ They do not necessarily trump all of the employees' statutory or legal rights. ${ }^{163}$ Consequently, courts ought to consider employees'

159. See, e.g., Hosanna-Tabor, $132 \mathrm{~S}$. Ct. at 705 (applying an absolutist ministerial exception limits employee from arguing that finding in favor of the employee would vindicate employment discrimination goals).

160. At some point, accommodating the religious rights of employers may go too far. See Corp. of the Presiding Bishop of the Church of Jesus Christ of LatterDay Saints v. Amos, 483 U.S. 327, 334-45 (1987) (noting that, at some point, accommodating the employer's free exercise rights may become "unlawful fostering of religion" (quoting Hobbie v. Unemployment Appeals Comm'n of Fla., 480 U.S. $136,145(1987))$ ).

161. See Burwell v. Hobby Lobby Stores, Inc., 134 S. Ct. 2751, 2759 (2014) (holding that "exercise of religion" provision in RFRA allows employer to avoid certain requirements of the ACA).

162. See Hosanna-Tabor, 132 S. Ct. at 710 .

163. See id. (noting that the ministerial exception may not bar a minister from pursuing other claims against the church flowing from the minister's termination); see also Hobby Lobby, $134 \mathrm{~S}$. Ct. at 2783 (noting that the employer's exercise of religion will not necessarily allow it to avoid all responsibilities under 
arguments regarding their statutory rights. Unfortunately, given how the issue of employer free exercise rights is currently framed, employees are very unlikely to have their statutory rights seriously considered when the issue is the free exercise rights of employers.

This is not a matter of simply having the employee sue to enforce his or her statutory rights. Employee rights are not necessarily addressed when employees sue to enforce their statutory rights. Except when the employer is a governmental entity, an employee suing for rights asserts those rights against another private party-the employer. Consequently, the enforcement of the statute and the employee's statutory rights may depend on whether the statute that provides those rights is considered too large an infringement on the employer's free exercise rights. ${ }^{164}$ The statute can be analyzed as the government's limitation of the employer's free exercise rights if the employee's rights clash with the employer's free exercise rights. Similarly, the dispute can be analyzed as an Establishment Clause issue -if the employee is suing for his or her own free exercise rights under the statute-depending on how protective the statute is of the employee's free exercise rights. ${ }^{165}$ Nonetheless, the centrality of the employee's statutory rights-the genesis of the suit-fades as the dispute is reconfigured as a dispute involving the employer's rights and government's regulation of those rights under the First Amendment. Consequently, seriously considering employee rights may require that the structure of employer free exercise litigation be reframed to consider the parties whose rights are truly at stake: the employee and the employer's stakeholders.

the ACA).

164. See Kennedy v. St. Joseph's Ministries, Inc., 657 F.3d 189, 194 (4th Cir. 2011) (noting that Title VII's religious organization exemption represents a balance between the government's right to regulate the employer and the employer's right to be free to exercise religion).

165. If a statute is too protective of religious rights-employer's or employee's-it can trigger Establishment Clause concerns. See Amos, 483 U.S. at 336 (discussing whether Title VII's exemption allowing religious employers to discriminate on the basis of religion violated the Establishment Clause); Trans World Airlines v. Hardison, 432 U.S. 63, 90 (1977) (discussing whether Title VII's requirement that an employer reasonably accommodate an employee's religious practice violated the Establishment Clause). 


\section{CONCLUSION}

Free exercise litigation tends to involve the government regulation of individuals. In most such litigation, the adversaries are the individual and the government. There may be spillover effects from the litigation's resolution that affect non-parties, but the adversaries bear the brunt of the litigation's results. That is not the case when an employer's free exercise rights are at issue. In such cases, an employmentrelated statute will usually be in dispute. If the government loses, the employee loses and must bear the brunt of the loss. If the employer loses, its stakeholders lose (their rights are actually at issue) and must bear the brunt of the loss. Given that the owners/stakeholders of the corporation and the employees arguably are the real interested parties, their interests in the litigation ought to be directly at issue.

The litigation of employer free exercise rights ought to be reframed as a dispute between the stakeholders' free exercise rights and the employees' rights under the relevant statute. This reframing would require that the Court take seriously the notion that the employer's stakeholders are the real parties and their free exercise rights are actually at issue. Consequently, the Court would need to ask, "How are the stakeholders' free exercise rights affected by the application of the statute at issue to the employee who has sued?" To be clear, the question is not merely whether the stakeholders would prefer that their entity's actions reflect their religious beliefs. Presumably, they do want that. Rather, the question is whether or how the stakeholders' free exercise rights are harmed by having an entity with which the stakeholders are associated comply with a statute that provides employee rights. The question may seem to ask too much about the content of the stakeholders' religious views. However, the Court has made the question necessary by siting the stakeholders' collective free exercise rights in the employer.

'The core issue-how stakeholders' free exercise rights are affected by the application of the statute at issue-remains the same, but its implications change, depending on whether the employer is a religious organization or a for-profit corporation or some type of entity. The implications are different because the nature of the transmission of the stakeholders' free exercise rights through an organization differs depending on whether 
the organization is a religious organization or a for-profit corporation. The transmission of church members' free exercise rights through their church may be strong, whereas the transmission of owners' free exercise rights though their corporation may be weak. ${ }^{166}$ The issue is difficult to resolve, but it is the right issue to consider. If the Court properly considers the issue in future cases, it could eliminate some of the problems inherent in litigating employer free exercise rights.

166. See Hosanna-Tabor, $132 \mathrm{~S}$. Ct. at 710 (noting the importance of "the interest of religious groups in choosing who will preach their beliefs, teach their faith, and carry out their mission"). 
UNIVERSITY OF COLORADO LAW REVIEW 